\title{
Cytotoxic Activities in Vitro of Flower Extracts of Three Species of Aloe Growing in Yemen: Aloe Rubroviolaceae, Aloe Vera and Aloe Sabaea, against Eleven Types of Cancer Cell Lines
}

Hassan Mohammed Al-Mahbashi ${ }^{1}$ and Hassan A. Al-Shamahy ${ }^{2 *}$

${ }^{1}$ Department of Forensic Medicine and Clinical Toxicology, Faculty of Medicine and Health Sciences, Sana'a University, Sana'a, Republic of Yemen.

${ }^{2}$ Medical Microbiology and Clinical Immunology Department, Faculty of Medicine and Health Sciences, Sana'a University, Republic of Yemen.

*Corresponding author: Hassan A. Al-Shamahy, Medical Microbiology and Clinical Immunology Department, Faculty of Medicine and Health Sciences, Sana'a University, Republic of Yemen

Received date: July 15, 2021; Accepted date: August 14, 2021; Published date: August 23, 2021

Citation: Hassan M. Al-Mahbashi and Hassan A. Al-Shamahy (2021). Cytotoxic Activities in Vitro of Flower Extracts of Three Species of Aloe Growing in Yemen: Aloe Rubroviolaceae, Aloe Vera and Aloe Sabaea, against Eleven Types of Cancer Cell Lines. J Clinical Research and Reports, 8(5); DOI:10.31579/2690-1919/187

Copyright: ( 2021 Hassan A. Al-Shamahy. This is an open access article distributed under the Creative Commons Attribution License, which permits unrestricted use, distribution, and reproduction in any medium, provided the original work is properly cited.

\begin{abstract}
Background and aims: Natural products, especially plant extracts, have opened up great opportunities in the field of drug progress due to their chemical variety. The genus Aloe has long been used for medicinal uses in countless parts of the world. This study was designed to investigate the phytochemicals and anti-cancer capabilities of Aloe rubroviolaceae, Aloe vera and Aloe sabaea flowers.

Materials and Methods: The methanolic extracts of three types of plants traditionally used in Yemen to treat a variety of diseases have been tested in vitro for their potential anticancer activity on different human cancer cell lines. The cytotoxic activity of the methanolic extracts of tested plants was determined using eleven strains of human cancer cells, namely: MCF-7 (breast cancer), PC-3 (prostate cancer), HEP-2 (human epithelial carcinoma), MNFS-60 (myelogenous leukemia), CACO (intestinal cancer), A-549 (lung adenocarcinoma), HeLa (cervical cancer), RD (rhabdomyosarcoma), HepG2 (hepatocellular carcinoma), HCT-116 (colon cancer), and CHO-K1 (Chinese hamster ovary). A colorimetric sulforhodamine B assay was used to evaluate the in vitro cytotoxic activity of different extracts. Growth inhibition of 50\% (IC50) for each extract was calculated from the optical density of treated and untreated cells. Doxorubicin, a broad-spectrum anticancer drug was used as a positive control.
\end{abstract}

Results: More interesting cytotoxic activity was observed for Aloe vera extract more than Aloe sabaea and Aloe rubroviolaceae,_extract.

Conclusions: This study provides a preliminary screening for anti-proliferative activity of various Aloe species flowers extracts on different cancer cell lines. Different extracts of Aloe species significantly inhibit the growth of various cancer cell lines in a concentration-dependent manner. Further investigations are required to understand the possible mechanism(s) of action of these extract on various cancer cells and isolation of active phyto-chemicals.

Key Words: aloe species; cytotoxic activities; flower extracts; in vitro; Yemen; cosmetic properties; anti-cancer agents

\section{Introduction}

Aloe is a genus that contains more than 550 species of flowering succulent plants. The most widely known species is Aloe vera, or "true Aloe." It is described this because it is grown as a standard source for various pharmaceutical purposes. These species, as Aloe rubroviolaceae, Aloe vera, and Aloe sabaea are grown or harvested from the wild for similar applications [1-3]. The genus is inhabitant to tropical regions, South
Africa, Madagascar, Jordan, the Arabian Peninsula including Yemen and is endemic to a variety of islands in the Indian Ocean such as Yemeni Socotra, Reunion, Mauritius,_and the Comoros Islands. A few species have also been adapted in other areas such as the India, Mediterranean, South and North America, Australia, and the Hawaiian Islands [4]. Most varieties of Aloe have a rosette of large, thick, fleshy leaves. The flowers of the Aloe are tubular, often yellow, orange, pink, or red, and bush, densely clumped and drooping, at the apex of simple or branching stems 
devoid of leaves. Many varieties of Aloe appear without stems, with the rose growing directly at ground level; other varieties may have a branched or un-branched stalk from which the fleshy leaves sprout. They vary in color from gray to light green, and are sometimes striped or speckled. Some species of Aloe native to South Africa are tree-like (arborescent) [5]. Aloe species are often grown as an ornamental plant in both gardens and pots. Many types of Aloe are very decorative and are appreciated by collectors of succulents. Aloe vera is used internally and externally on humans as a folk or alternative medicine. Aloe species is known for its medicinal and cosmetic properties. About $75 \%$ of Aloe species are used locally for medicinal uses in addition to other herbal plants [6-9]. In Yemen, recent researches investigated the effect of herbal plants on viral and bacterial agents and protozoa in which traditional medicine and flavors are used in Yemen where a large number of people rely on herbal plants to treat their diseases $[10,11]$.

It is estimated that in 2018, there were 18.1 million new cases of cancer and 9.6 million deaths worldwide. About $20 \%$ of males and $17 \%$ of females will develop cancer at some point while $13 \%$ of males and $9 \%$ of females will expire from it. In 2008, roughly 12.7 million cancers were diagnosed and in 2010 just about 7.98 million people died. Cancers account for about $16 \%$ of deaths. The most common as of 2018 are lung cancer (1.76 million deaths), colorectal cancer $(860,000)$, stomach cancer $(780,000)$, liver cancer $(780,000)$ and breast cancer $(620,000)$. [12,13]. According to the limited Yemeni Cancer Studies, the most common types of cancer among Yemeni children and adults were leukemia (33.1\%), lymphoma $(31.5 \%)$, central nervous system tumors $(7.2 \%)$, and bone tumors $(5.2 \%)$ [14-18]. The potential for natural products to be used as a source of anti-cancer agents was accepted in the 1950 s by the United States (the National Cancer Institute, NCI) is led by the late Dr. Jonathan Hartwell. NCI has made it a major contributions to the discovery of new naturally occurring anticancer agents through its holding and grant support, including an important program for plant and marine groups. Anti-cancer drugs, such as indole alkaloids. Vincristine, vinblastine, podophyllotoxin derivatives etoposide and teniboside are prominent chemical treatments of plant origin obtained either directly through isolation or derived from lead structures [19]. Aloe species that originated in the Arabian Peninsula are well recognized for their medicinal use and outside of this species. The traditional uses of Aloe species include wound and burn healing and topical treatment of skin diseases [20]. Several researchers have also uncovered the role of Aloe species in treating eye infections, stomach ailments, constipation and malaria [21,22]. The antimicrobial effect of $A$. perryi has also been reported [23]. Therefore, screening of higher plants for anticancer agents has been pursued on an international level, [24]. Yemen is characterized by its vast area, where variations in climate appear due to differences in elevations, which results in a great diversity of its plants. Yemen's botanicals are known for their use in folk and traditional medicine $[25,26]$. Thus, this study aims to explore the antiproliferative potential of several Aloe species flowers against several human cancer cell lines.

\section{Materials and Method}

Sample collection and Identification: The flowers of Aloe Rubroviolaceae and Aloe Vera were collected from saber area in the city of Taiz and Badan Mountains (Ibb) respectively, while flowers of Aloe Sabaea were collected from Miatam and Aldlel villages (Ibb). The taxonomy work and identification of the plants was confirmed by Professor: Abdul Walli Al-Kholidy, Department of Botany, Faculty of Agriculture, Sana'a University, Yemen. The flowers of all plants were collected during the flowering stage in November 2017.

Preparation of Samples: The flowers of the three plants were dried separately in the air and ground to a coarse powder. The powder was then stored in airtight containers at room temperature until use.
Preparation of ethanol extracts: The dried flower powder was extracted separately by soaking in sufficient amount of ethanol (99\%) with repeated shaking for 1 week and filtered. Each flower filtrate was evaporated and dried separately under reduced pressure at $45^{\circ} \mathrm{C}$ using a rotary evaporator (Buchi Rotavapor R-200, Serial No. 05009474, Switzerland) and the process was repeated twice until the extraction was complete.

Phytochemical screening: TLC technology was used to identify the components of ethanolic extracts of plant flowers using a TLC plate coated with 60 F254 silica gel, $20 \times 20 \mathrm{~cm}$ (Merck, Germany). The first developed chromatograms were examined under UV light (VilberLourmat, French) at wavelengths of $254 \mathrm{~nm}$ and $365 \mathrm{~nm}$. Then each chromatogram was analyzed for the presence of biologically active components by spraying with appropriate reagents.

Cytotoxicity assay: The cytotoxicity of the extracts was tested against eleven types of cancer cell line, Human hepatocellular carcinoma (HepG2), human colon cancer (HCT-116), human breast cancer (MCF7), human lung adenocarcinoma (A-549), human prostate cancer (PC3), human epithelial carcinoma (HEp-2) and humancervical cancer (HELA), myeloid leukemia (M-NFS- 60), human epithelial colorectal adenocarcinoma (CACO-2), chinese Hamster Ovary (CHO-K1), and rabdomyosarcoma(RD). Cells were obtained from the American Type Culture Collection (ATCC). Tumor cells were propagated in RPMI-1640 medium supplemented with $10 \%$ heat inactivated fetal bovine serum, $1 \%$ L-glutamine, HEPES buffer and $50 \mu \mathrm{g} / \mathrm{ml}$ gentamicin. All cells were maintained at $37{ }^{\circ} \mathrm{C}$ in a humidified $5 \% \mathrm{CO}_{2}$ and sub-cultured twice a week.

Evaluation of cellular cytotoxicity: The tested cell lines were seeded in a 96-well plate at a cell concentration of $1 \times 10^{4}$ cells per well in $100 \mu \mathrm{l}$ of growth medium. Fresh medium containing different concentrations of plant extract was added 24 hours after sowing. Serial two-fold dilutions of the test chemical compound were added to confluent cell monolayers dispensed into 96-well, flat-bottomed microtitre plates (Falcon, NJ, USA) using a multichannel pipette. Microtiter plates were incubated at $37^{\circ} \mathrm{C}$ in a humidified incubator with $5 \% \mathrm{CO}_{2}$ for $48 \mathrm{~h}$. Three wells were used for each test sample concentration. Control cells were incubated without test sample and with or without DMSO. At the end of the incubation period, the production of viable cells was determined by a colorimetric method. Briefly, media was aspirated and crystal violet solution (1\%) was added to each well for at least $30 \mathrm{~min}$. The stain was removed and the dishes rinsed with tap water until all excess stains were removed. Glacial acetic acid (30\%) was then added to all wells and mixed well, and the absorbance of the plates was then measured after gentle shaking on a microplate reader (TECAN, Inc.), using a test wavelength of $590 \mathrm{~nm}$. The absorbance was proportional to the number of surviving cells remaining in the culture plate. All results were corrected for background absorbance detected in the wells without adding dye. The treated samples were compared with the cellular control in the absence of the tested compounds. All experiments were performed in triplicate. The effect on cell growth was calculated as the difference in the absorbance ratio in the presence and absence of the tested extracts and shown in the doseresponse curve. The concentration at which cell growth was inhibited to $50 \%$ of the control (IC50) was obtained from the dose-response curve.

\section{Statistical Analysis}

The percentage cell viability was calculated using the Microsoft Excel®. Percentage cell viability was calculated as follows:

$\%$ Cell viability $=($ Mean Abs of control $)($ Mean Abs of test metabolite $) /$ (Mean Abs control) x100

Where: Abs: absorbance at $590 \mathrm{~nm}$.

Ethical Approval 
Ethical approval was obtained from the Medical Research and Ethics Co mmittee of the College of Medicine and Health Sciences, Sana'a Univers ity with reference number (121) on 13/02/2017.

\section{Results}

Cytotoxicity of ethanolic extracts of flowers from three species of Aloe against eleven cancer cell lines (MCF-7, PC-3, HEP-2, MNFS-60, CACO, A-549, HELA, RD, HepG2, HCT-116, and CHO-K1) using the Crystal Violet Staining Assay and evaluated according to American Cancer Institute guidelines. Figures 1-11 and Table 1 show the results and reveal that Aloe Vera flower extract showed significant dose-dependent cytotoxic activity against four cell lines (CACO, A-549, RD, HCT-116) with IC50 values of $14.6 \pm 0.65,12 \pm 0.50$ and $14.7 \pm 1.88$ and $14 \pm 0.46$, respectively. However, Aloe Sabaea flower extract exerts a very low cytotoxic activity against cell lines, compared to Aloe Vera extract. IC50 indicated that the most cytotoxic effect of Aloe Vera extract was against the A-549 cell line (IC50 = $43.6 \pm 3.07)$. On the other hand, Aloe Rubroviolaceae flower extract showed little cytotoxic activity against three cell lines (CACO, A-549, HCT-116) with IC50 = 30.1 $\pm 0.95,26.5$ \pm 1.05 and $29.7 \pm 0.78$, respectively.

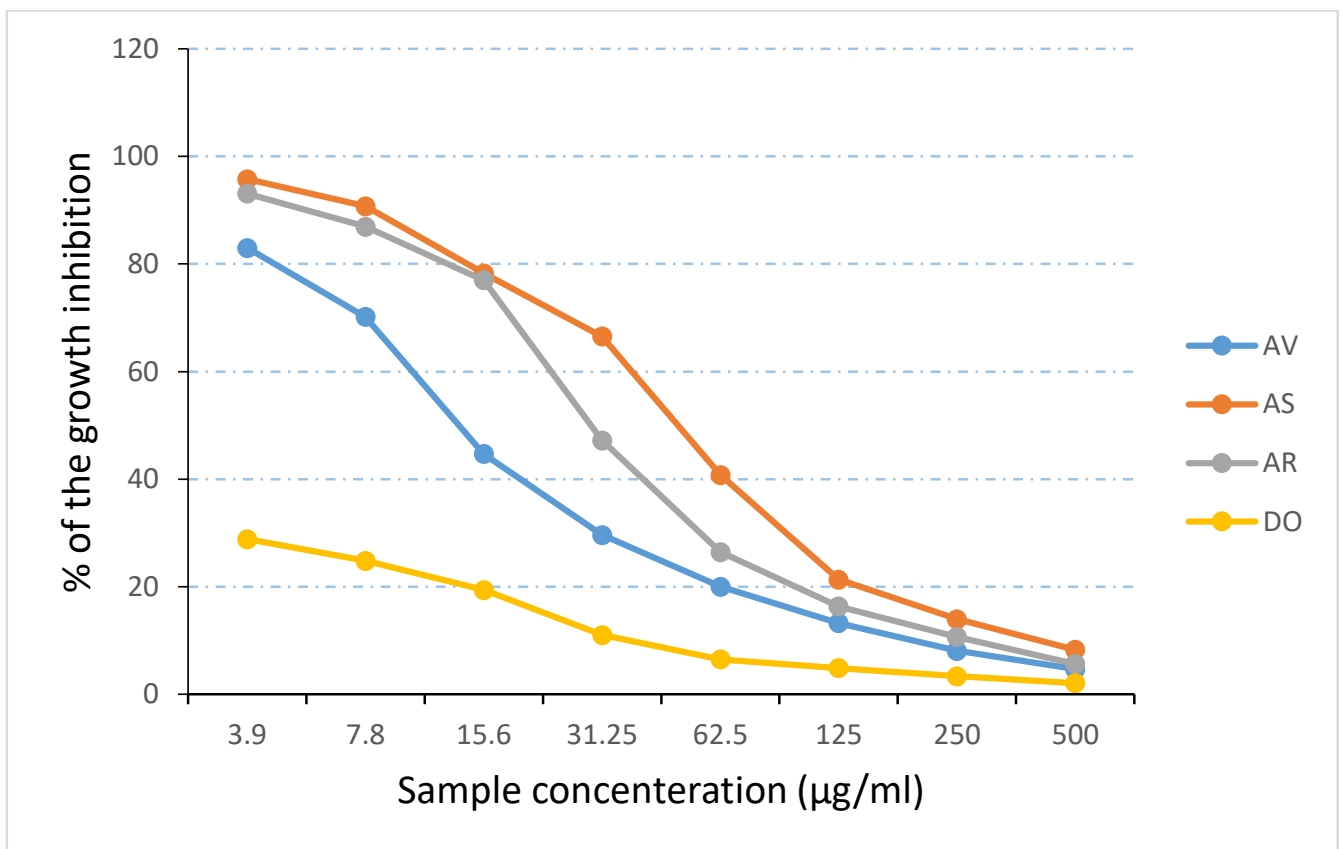

Figure 1. Percentage inhibition of cell growth of Aloe Vera (AV), Aloe Sabaea (AS), Aloe Rubroviolaceae (AR) extracts and Doxorubicin (DO) against the HCT-116cell line

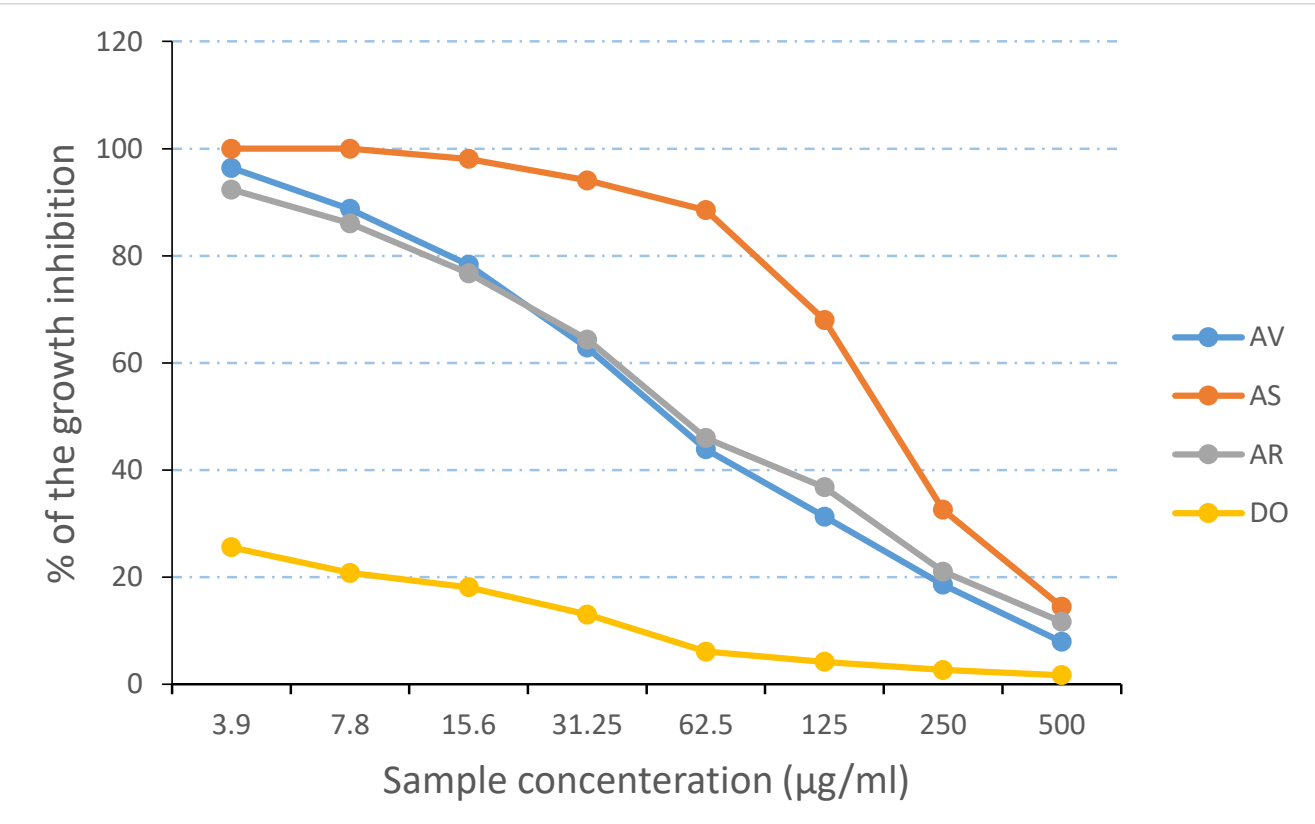

Figure 2. Percentage inhibition of cell growth of Aloe Vera (AV), Aloe Sabaea (AS), Aloe Rubroviolaceae (AR) extracts and Doxorubicin (DO) against the HpeG2 cell line 


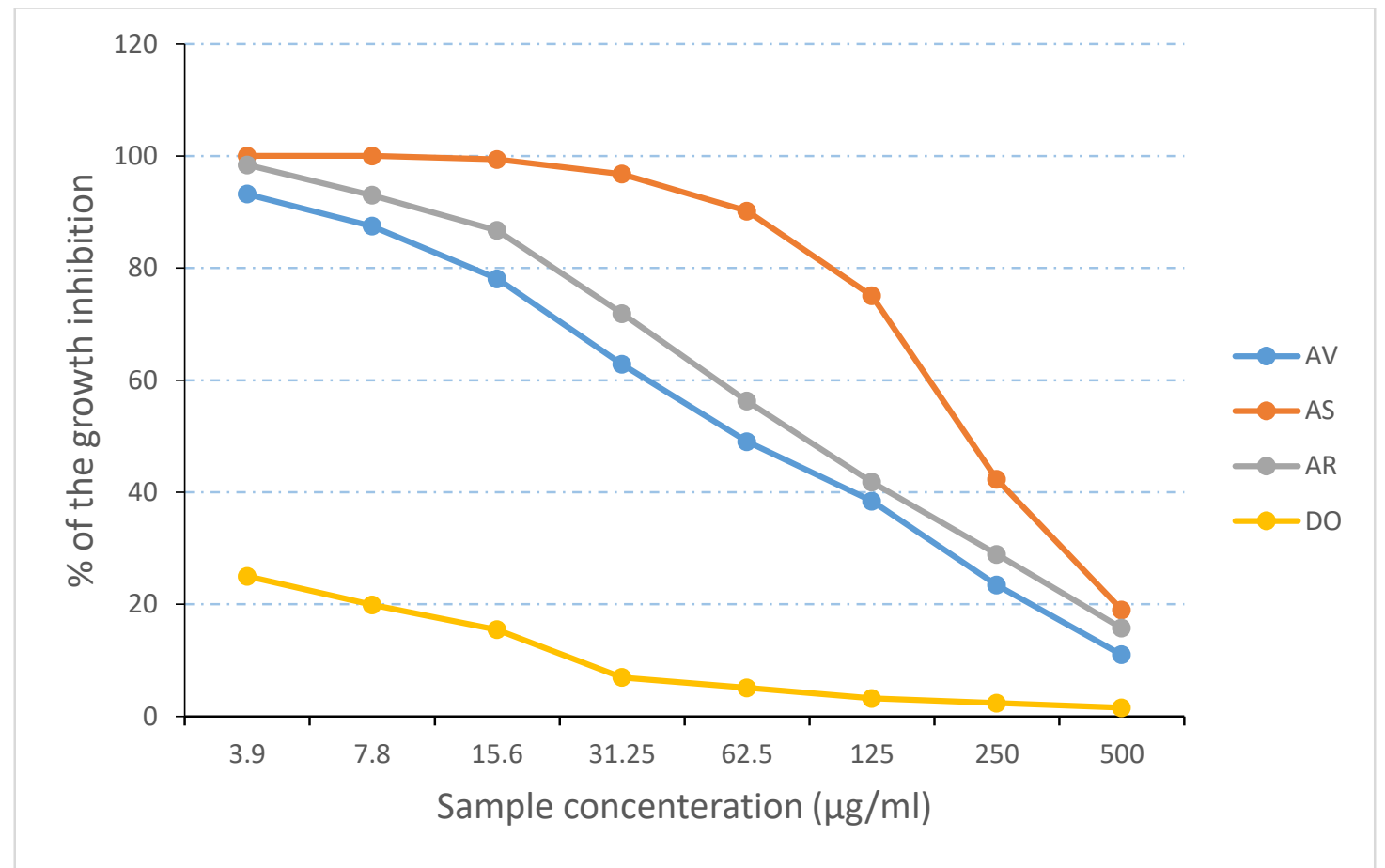

Figure 3. Percentage inhibition of cell growth of Aloe Vera (AV), Aloe Sabaea (AS), Aloe Rubroviolaceae (AR) extracts and Doxorubicin (DO) against the MCF-7 cell line

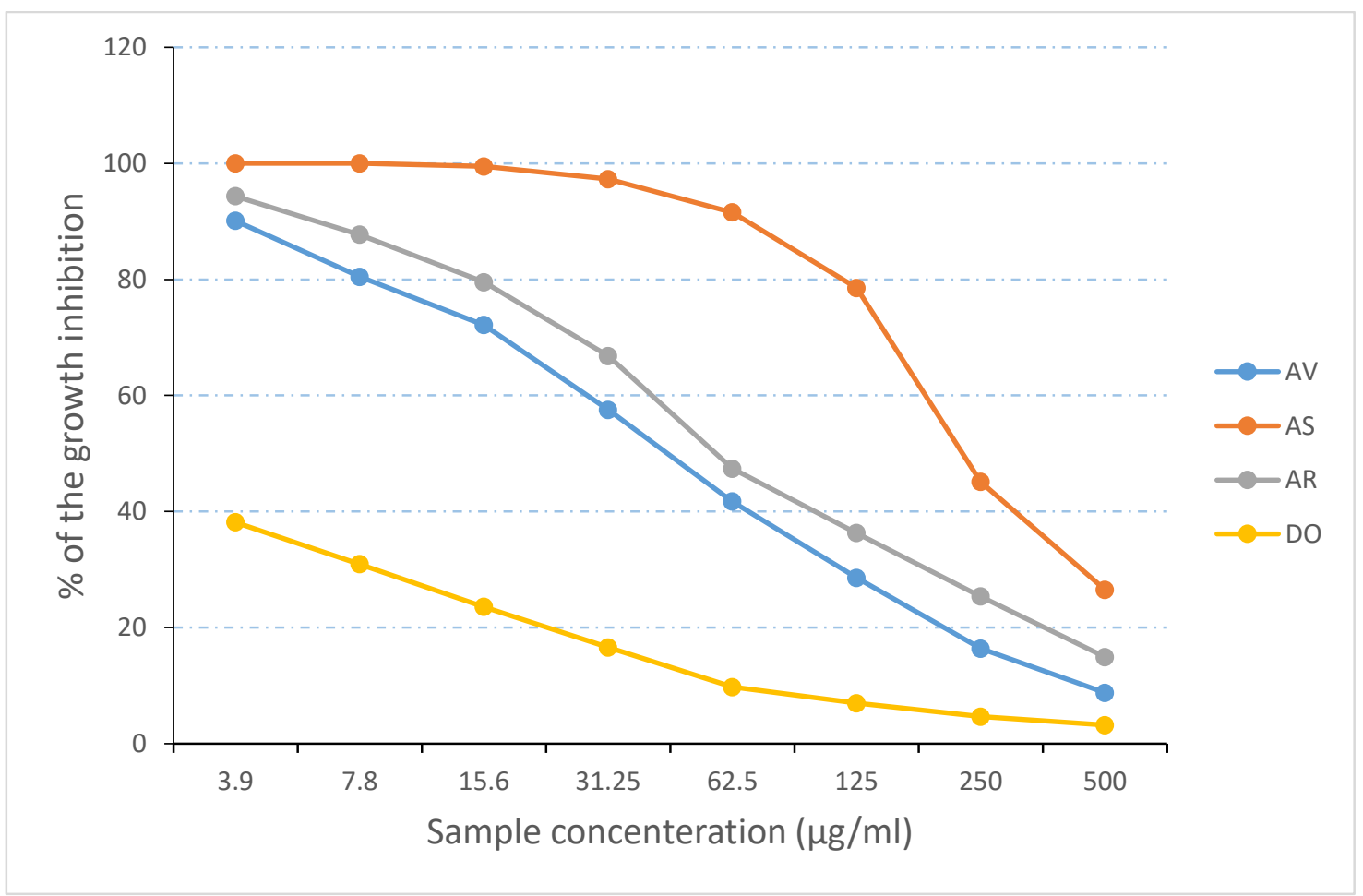

Figure 4. Percentage inhibition of cell growth of Aloe Vera (AV), Aloe Sabaea (AS), Aloe Rubroviolaceae (AR) extracts and Doxorubicin (DO) against the PC3cell line 


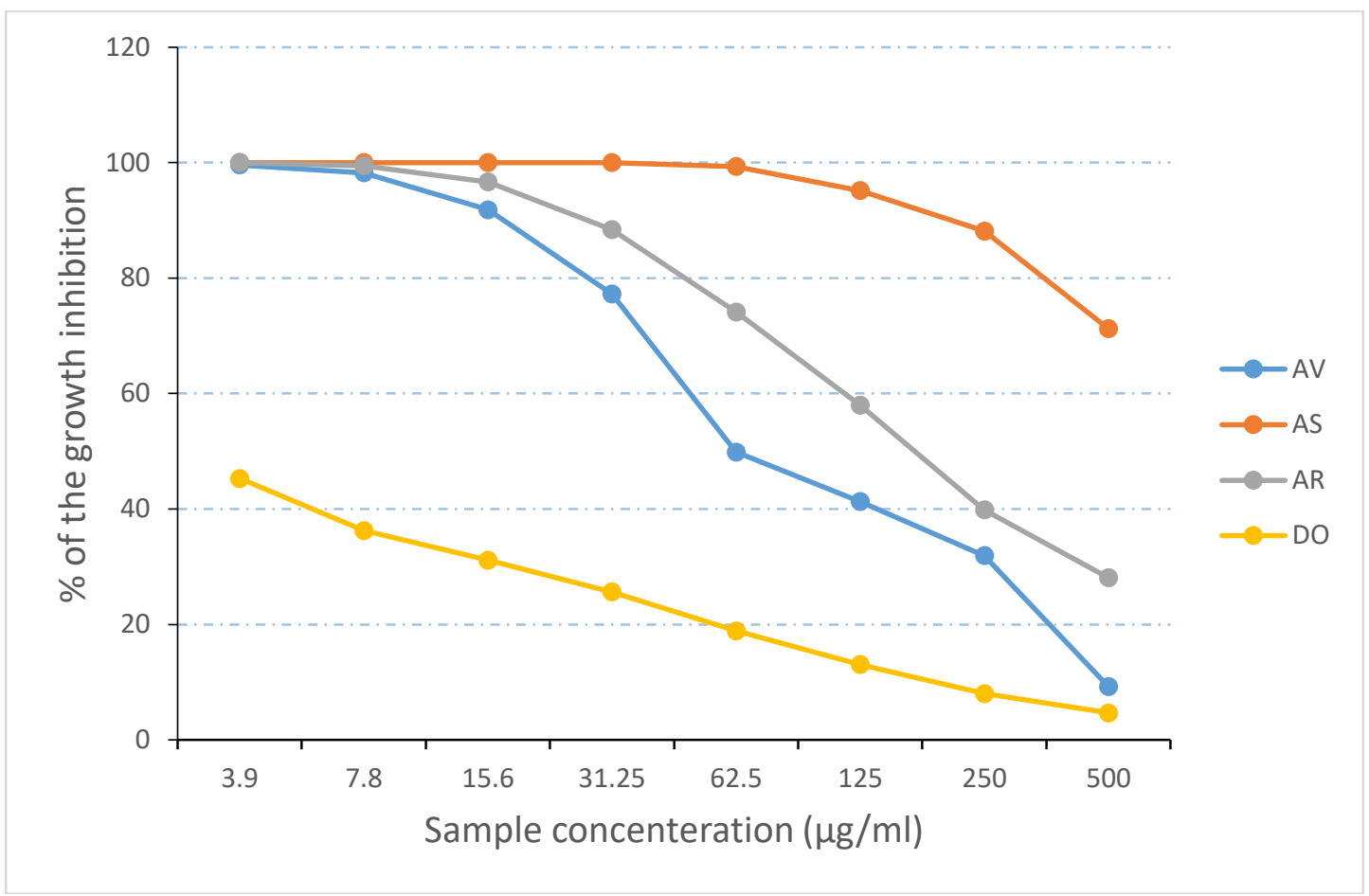

Figure 5. Percentage inhibition of cell growth of Aloe Vera (AV), Aloe Sabaea (AS), Aloe Rubroviolaceae (AR) extracts and Doxorubicin (DO) against the HEP-2cell line.

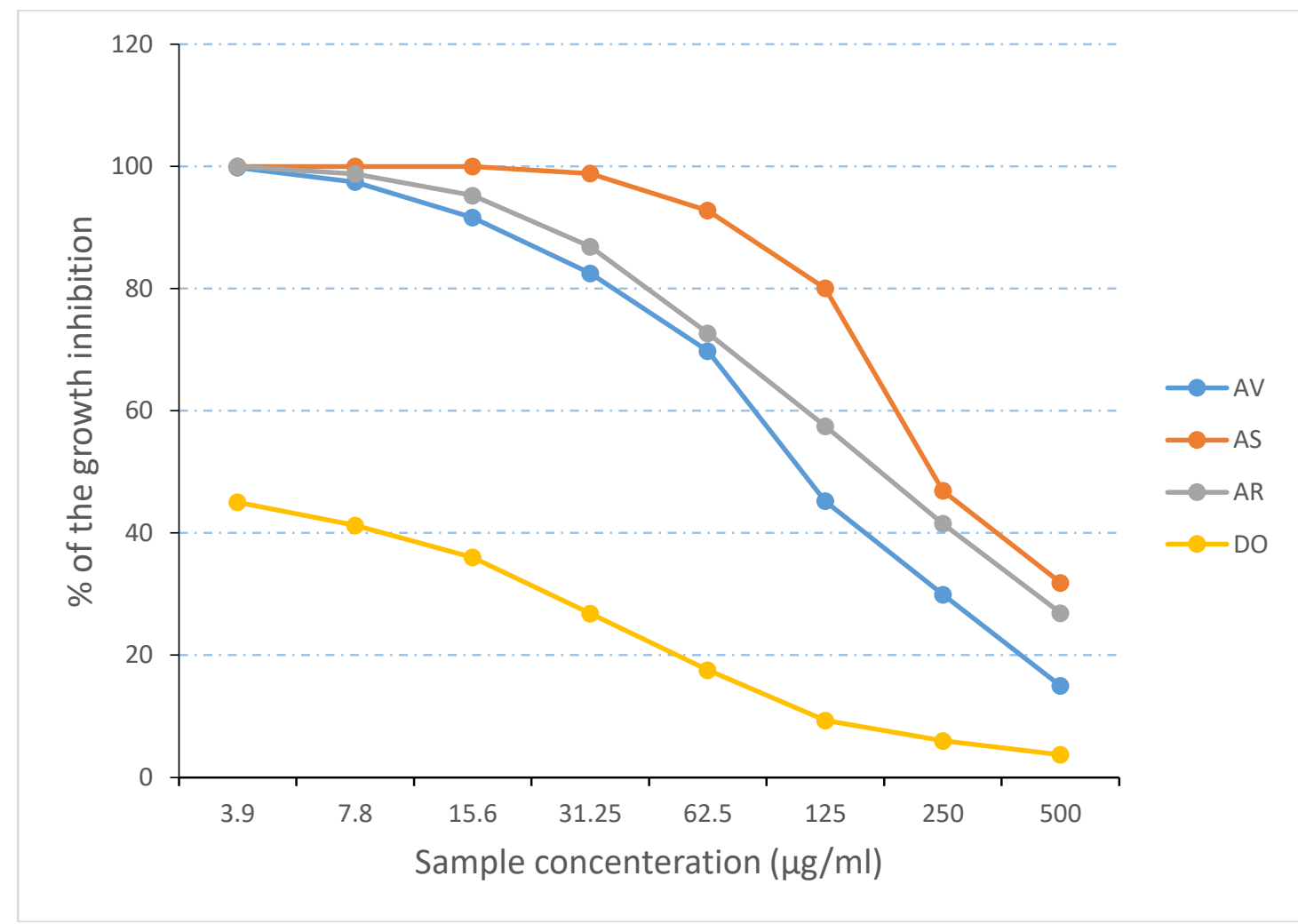

Figure 6. Percentage inhibition of cell growth of Aloe Vera (AV), Aloe Sabaea (AS), Aloe Rubroviolaceae (AR) extracts and Doxorubicin (DO) against the MNFS-60 cell line 


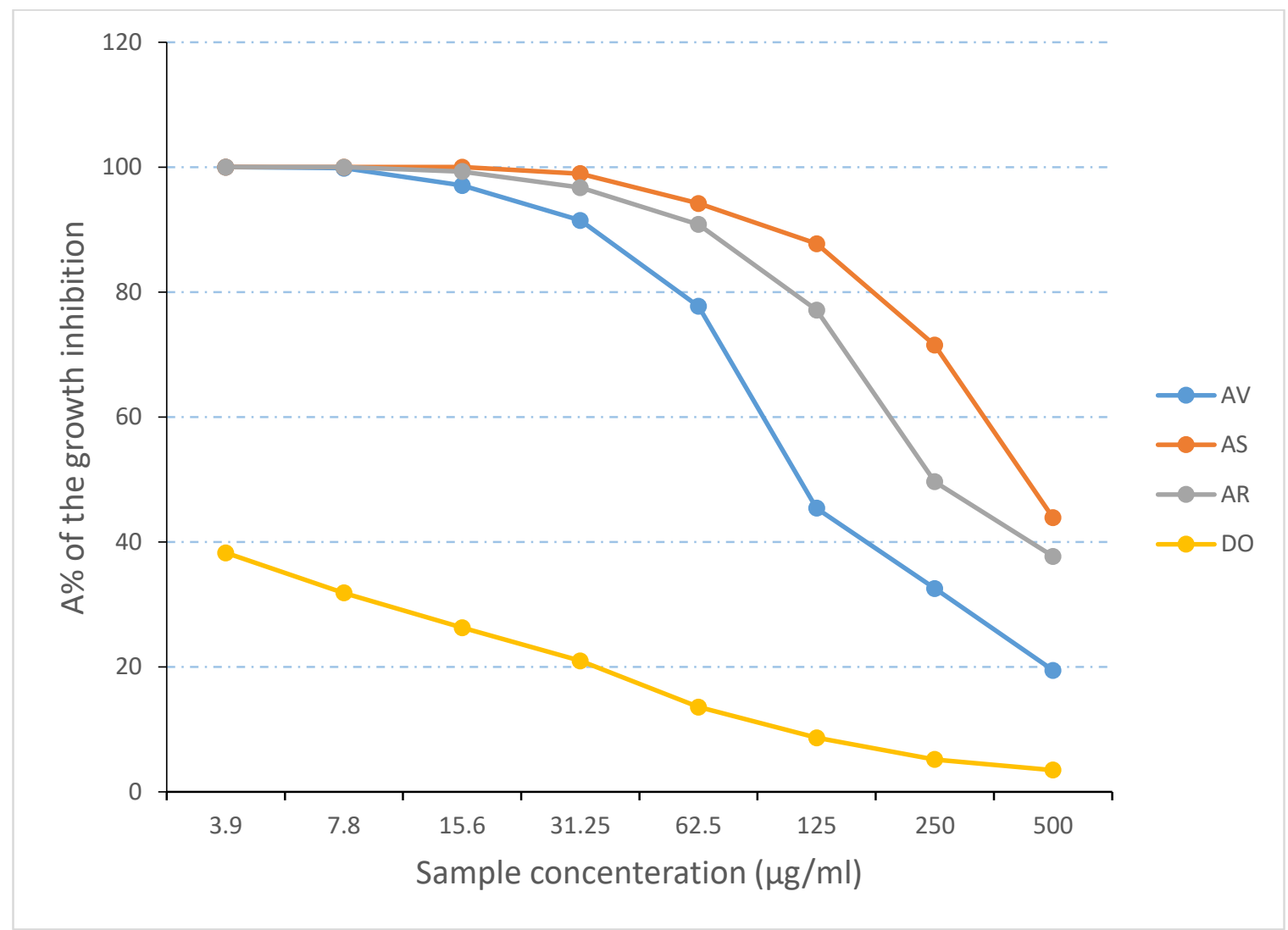

Figure 7. Percentage inhibition of cell growth of Aloe Vera (AV), Aloe Sabaea (AS), Aloe Rubroviolaceae (AR) extracts and Doxorubicin (DO) against the CACO cell line

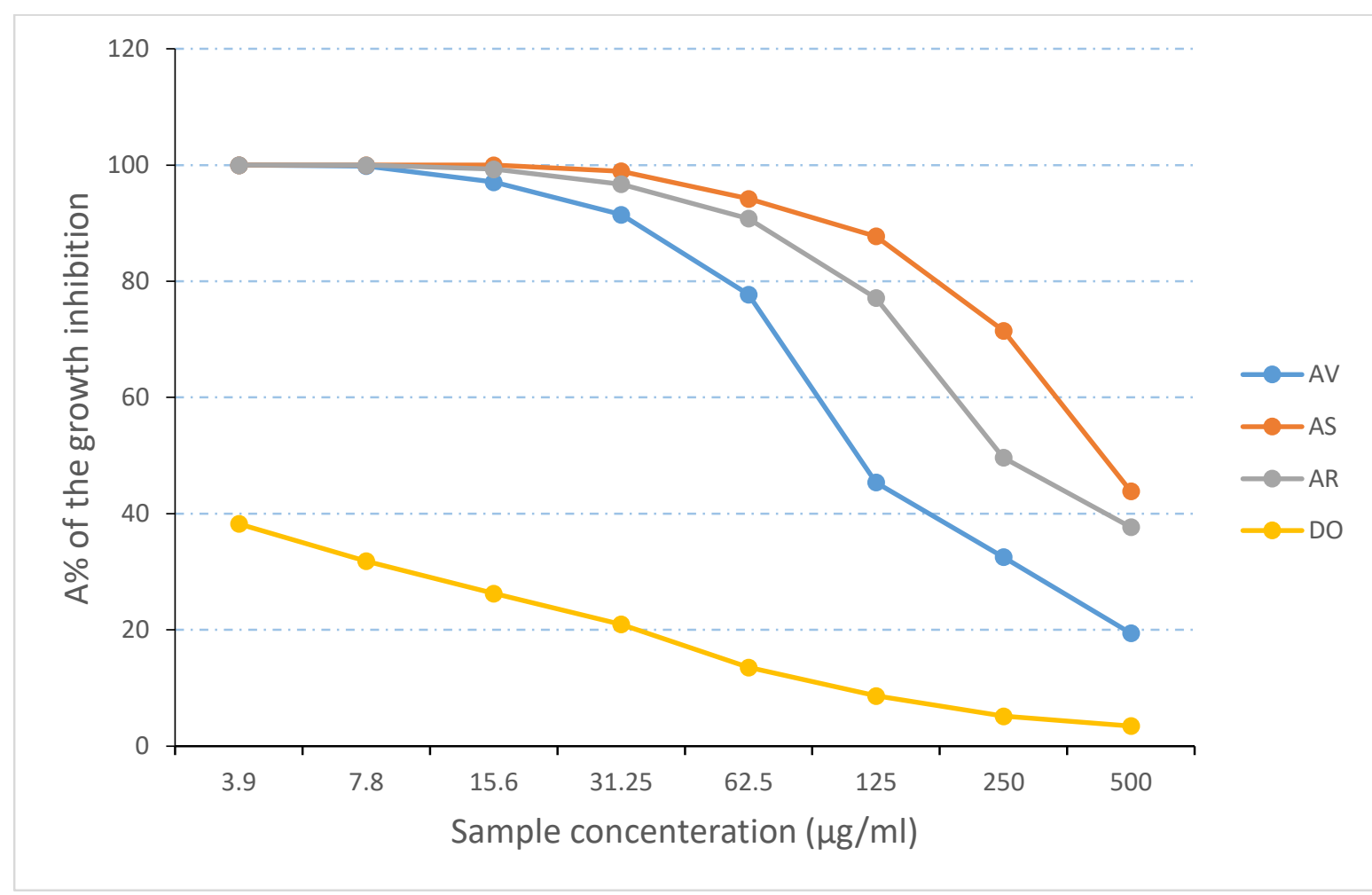

Figure 8. Percentage inhibition of cell growth of Aloe Vera (AV), Aloe Sabaea (AS), Aloe Rubroviolaceae (AR) extracts and Doxorubicin (DO) against the $\mathrm{CHO}-\mathrm{K} 1$ cell line. 


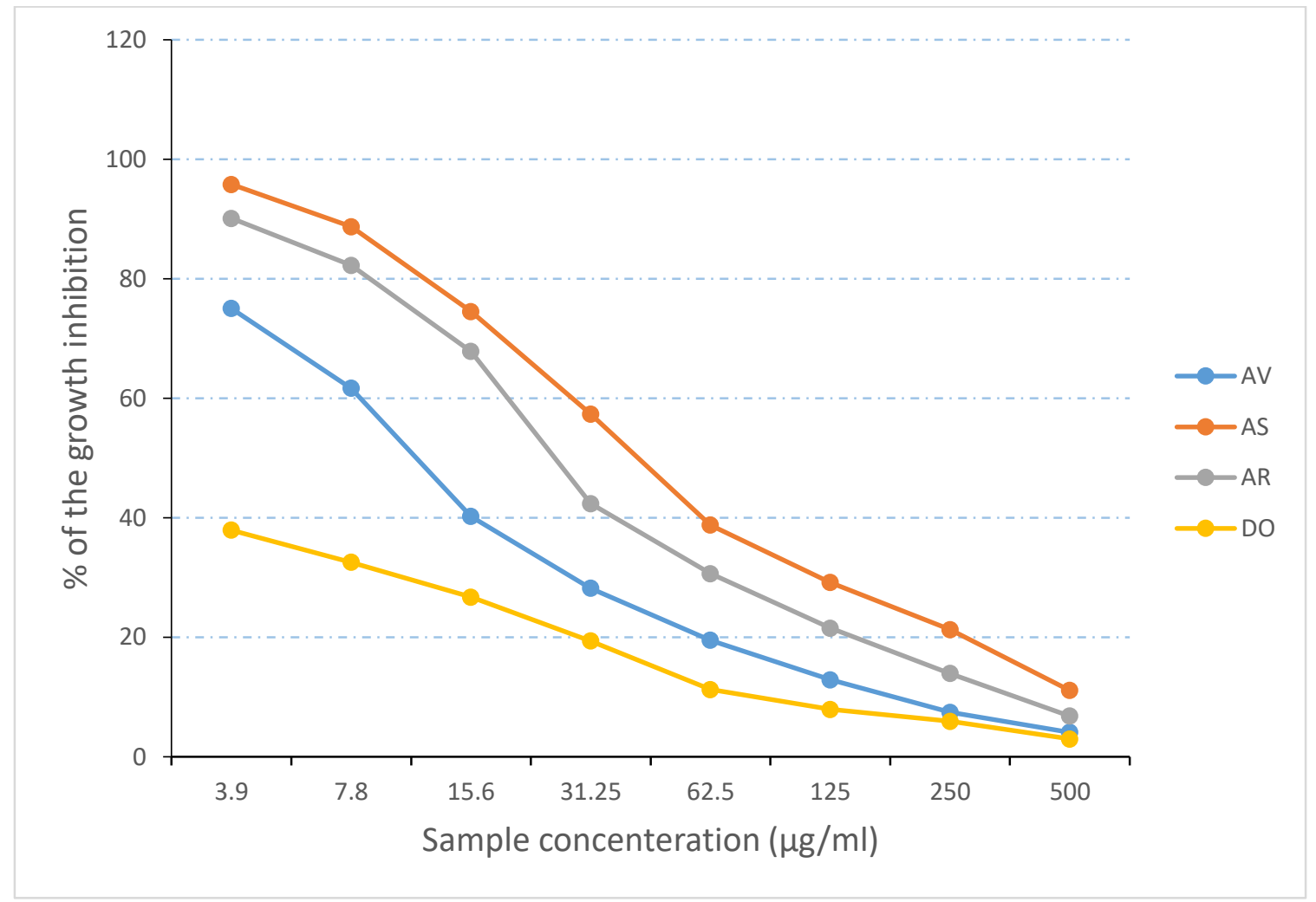

Figure 9. Percentage inhibition of cell growth of Aloe Vera (AV), Aloe Sabaea (AS), Aloe Rubroviolaceae (AR) extracts and Doxorubicin (DO) against the A-549 cell line

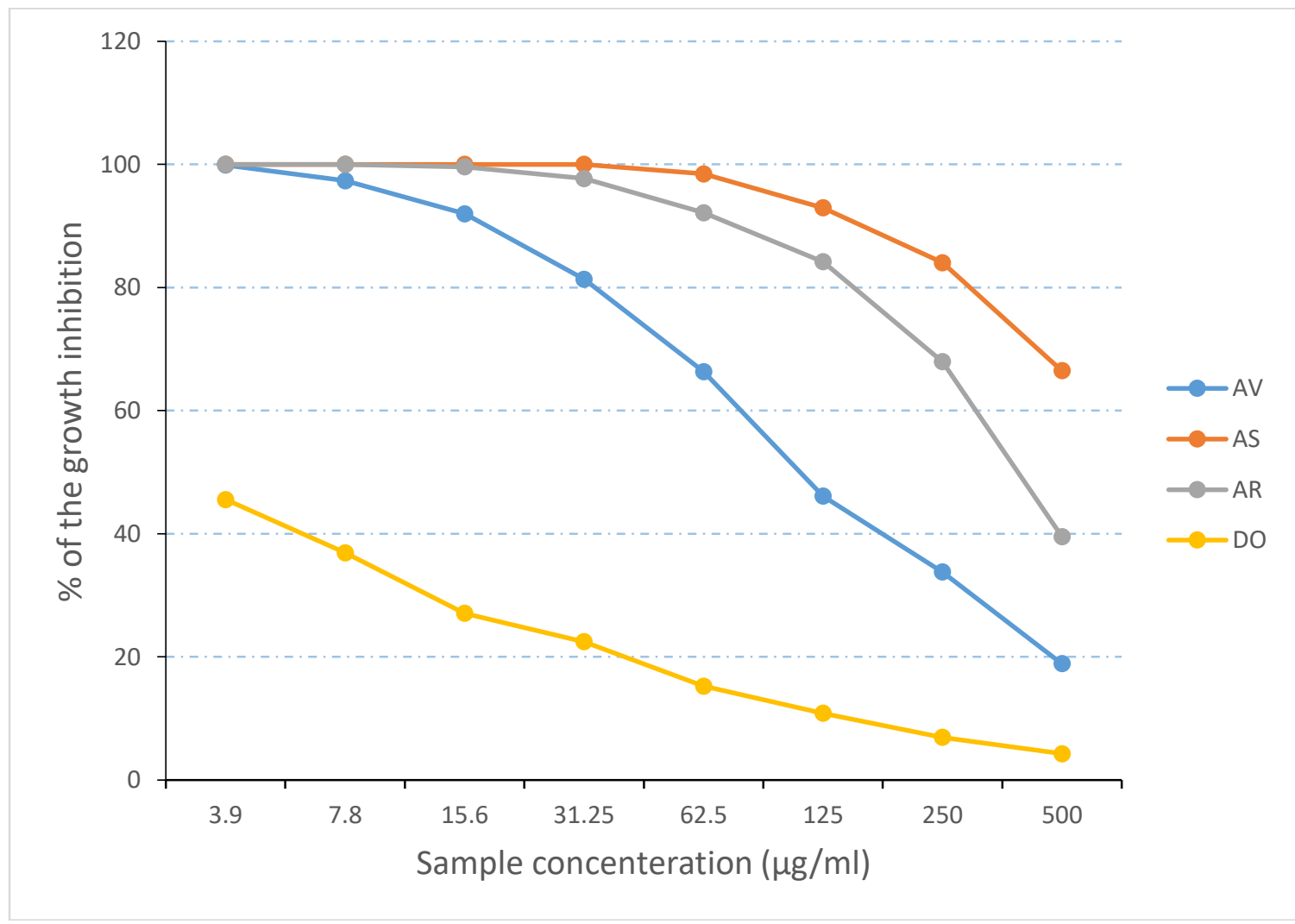

Figure 10. Percentage inhibition of cell growth of Aloe Vera (AV), Aloe Sabaea (AS), Aloe Rubroviolaceae (AR) extracts and Doxorubicin (DO) against the HELA cell line 


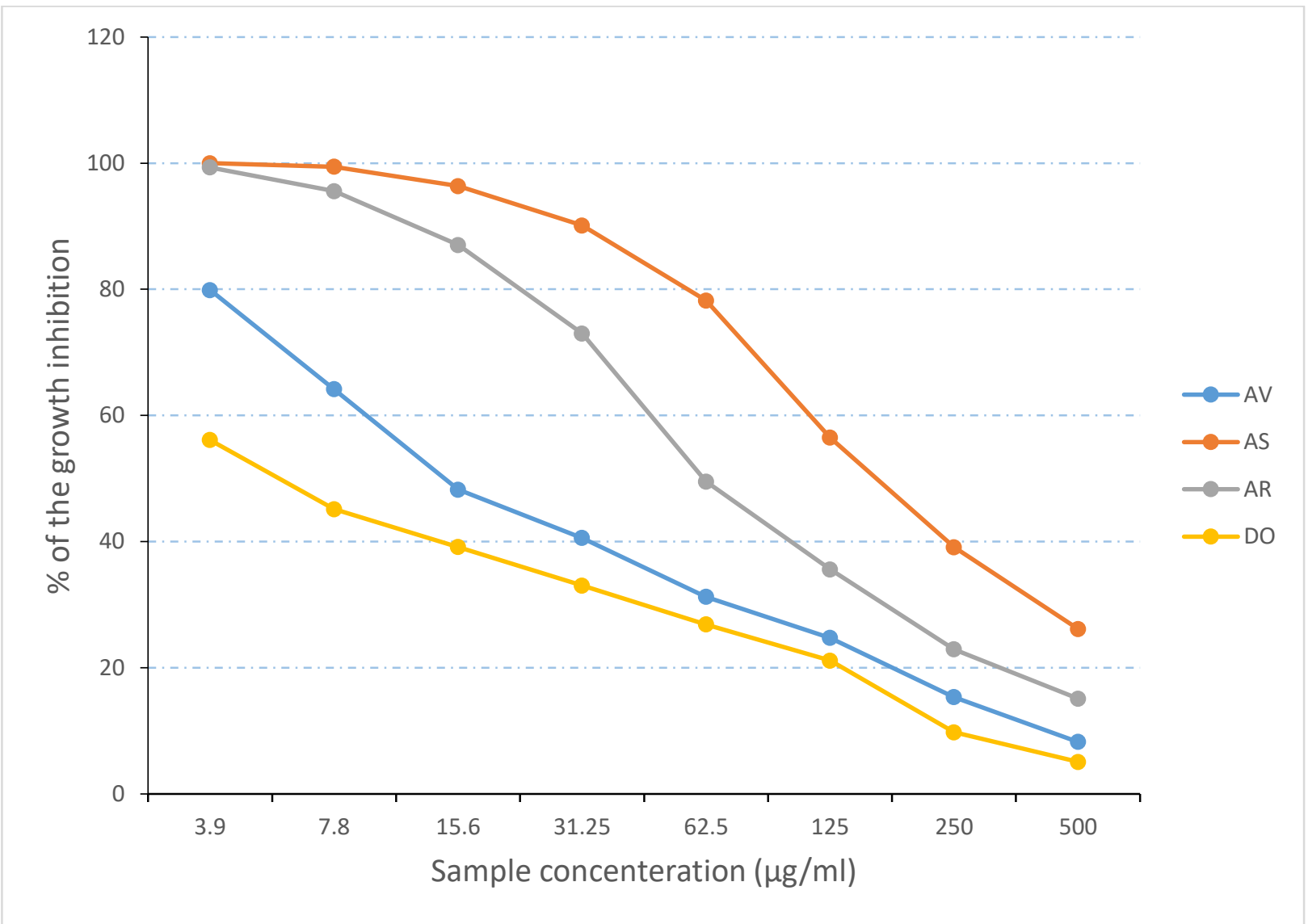

Figure 11. Percentage inhibition of cell growth of Aloe Vera (AV), Aloe Sabaea (AS), Aloe Rubroviolaceae (AR) extracts and Doxorubicin (DO) against the RD cell line

\begin{tabular}{|c|c|c|c|c|}
\hline Cell Lines & Aloe Vera & Aloe Sabaea & Aloe Rubroviolaceae & Doxorubicin \\
\hline MCF-7 & $60.3 \pm 5.17$ & $>100$ & $89.5 \pm 14.9$ & $0.35 \pm 0.02$ \\
\hline PC-3 & $46.1 \pm 6.07$ & $>100$ & $58.3 \pm 1.57$ & $1.68 \pm 0.15$ \\
\hline HEP-2 & $62.3 \pm 3.19$ & $>500$ & $>100$ & $3.58 \pm 0.11$ \\
\hline MNFS-60 & $>100$ & $>100$ & $30.1 \pm 0.95$ & $1.71 \pm 0.03$ \\
\hline CACO & $14.6 \pm 0.65$ & $92 \pm 5.81$ & $26.5 \pm 1.05$ & $0.95 \pm 0.16$ \\
\hline A-549 & $12 \pm 0.50$ & $43,6 \pm 3.07$ & $>100$ & $3.56 \pm 0.12$ \\
\hline HELA & $>100$ & $>500$ & $61.8 \pm 4.44$ & $6.07 \pm 0.22$ \\
\hline RD & $14.7 \pm 1.88$ & $>100$ & $55.7 \pm 3.09$ & $0.36 \pm 0.02$ \\
\hline HepG2 & $52.4 \pm 4.79$ & $>100$ & $29.7 \pm 0.78$ & $0.49 \pm 0.04$ \\
\hline HCT-116 & $14 \pm 0.46$ & $51.3 \pm 4.08$ & $>100$ & $0.84 \pm 0.06$ \\
\hline CHO-K1 & $>100$ & $>100$ & 300 & 12 \\
\hline
\end{tabular}

Cytotoxic activity is expressed as $\mathrm{IC50}(\mu \mathrm{g} / \mathrm{mL}) \pm \mathrm{SD}(\mathrm{n}=3)$, which is the concentration of extract at which $50 \%$ of cell growth was inhibited relative to cells incubated in the presence of $<0.1 \%$ DMSO vehicle control. All cell lines were treated with doxorubicin as a positive control. MCF-7 (breast cancer), PC-3 (prostate cancer), HEP-2 (human epithelial carcinoma), MNFS-60 (myelogenous leukemia), CACO (intestinal cancer), A-549 (lung adenocarcinoma), HeLa (cervical cancer), RD (rhabdomyosarcoma), HepG2 (hepatocellular carcinoma), HCT-116 (colon cancer) and CHO-K1 (Chinese hamster ovary).

Table 1. In vitro cytotoxic activities of Aloe Vera (AV), Aloe Sabaea (AS), Aloe Rubroviolaceae (AR) extracts against various carcinoma cell lines. 
In the present study, the cytotoxic activity was mainly observed in the ethanolic extract of Aloe Vera flowers, which showed the highest cytotoxic activity followed by the Aloe Rubroviolaceae flower extract, which showed moderate cytotoxic activity, while the Aloe Sabaea flower extract showed the lowest cytotoxic activity.

\section{Discussion}

Since the foundation of human history, innate products have been used for medicinal uses to treat a variety of diseases including cancer [27]. Many chemoprophylaxis are molecules derivative from plant resources or their synthetic analogues [28]. Vegetable lands were the most a significant foundation and at this time, around $60 \%$ of the drugs used to treat cancer have been isolated from natural products, as vincristine and vinblastine from Catharanthus roseus [29], Camptothecin from Camptothica acuminate [30], Taxol and docetaxel from Taxus Previfolia [31]. Fruits and vegetables are also known to reduce the risk of cancer in humans $[32,33]$. Some isolated compounds showed anticancer potential with low toxicity compared to conventional drugs, for example. Meisoindigo, isolated from the Chinese plant Indigofera tinctoria and flavopiridol, isolated from the Indian Dysoxylum binectariferum tree [34].

Regarding the results of the current study, cytotoxicity evaluation showed that low concentration of Aloe rubroviolaceae, Aloe vera and Aloe sabaea extracts significantly inhibited cell proliferation of CACO, A-549, RD and HCT-116 cell lines with a decrease in IC50. The results are in agreement with those of Al-Oqail et al. [27], who obtained a dosedependent response at different concentrations on HEp2, MCF-7, WISH and Vero cells. Our results also showed that CACO, A549, RD, and HCT116 cells were most sensitive to Aloe Vera among all studied cell lines and among the extracts, the highest inhibition of methanol extract was found in the A549 cell line with (IC50 = $12 \mu \mathrm{g} / \mathrm{ml}$ ), followed by with HCT-116 (IC50 = $14 \mathrm{mcg} / \mathrm{mL})$, RD $(\mathrm{IC} 50=14.7 \mu \mathrm{g} / \mathrm{mL})$, and CACO (IC50 $=14.6 \mu \mathrm{g} / \mathrm{mL})$. This type of variability between different cell lines was also reported by Heo et al. [35], who reported the anticancer effects of the plant extract on HEK-293, HCT-116, HeLa, MCF-7, Hep3B, SNU1066 and SNU-601 cell lines.

In an additional study, the discrepancy cytotoxic response of diverse cancer cell lines (HeLa, HepG2, MCF-7, CACO-2, and L929) was also reported and it was concluded that the plant extract efficiently inhibited cell proliferation depending on the concentration of the extract, also as types of cells [36]. The current results are also consistent with previous findings, that plant extracts reduce cell viability in human breast cancer (T47D) cells, due to the sensitivity of cancer cells to lethal flavonoids [37]. Furthermore, the growth-inhibitory consequence of components of Aloe Vera species in plants has also been confirmed in human uterine cancer (HeLa), melanoma (B16F10), human gastric cancer (MK-1) [38] and in other human cancer cell lines [39-41]. This growth-inhibitory activity may be a consequence of the plant extracts' ability to inhibit DNA synthesis as measured by incorporation of thymidine tritate into cells [42], leading to cell death [43].

\section{Conclusion}

In conclusions, this study presents the phytochemical analysis and preliminary examination of the anti-proliferative activity of extracts of different types of Aloe species on different cancer cell lines. We showed that different extracts of Aloe rubroviolaceae, Aloe vera and Aloe sabaea significantly inhibited the growth of different cancer cell lines (CACO, A-549, RD, HTC-116) in a concentration-dependent manner. Among all extracts, Aloe vera extract showed the greatest activity and A-549, HCT116 and RD cells were the most sensitive. In addition, the presence of phytochemicals such as phytosterols, phenols, flavonoids, proteins and glycosides has been confirmed. Further investigations are needed to understand the possible mechanism(s) of action of these extracts on different tumor cells and to isolate the active phytochemicals.

\section{Conflict of Interest}

"No conflict of interest associated with this work".

\section{Authors' Contributions}

All authors contributed equally to the design, implementation, statistical analysis and manuscript drafting. All authors read and approved the final manuscript.

\section{References}

1. The Plant List (2010). Version 1. Published on the Internet; (accessed July 2020)

2. NIH National Center for Complementary and Integrative Health "Aloe Vera: Science and Safety". April 2012. Retrieved 31 March2021.

3. Salehi, Bahare; Albayrak, Sevil; Antolak, Hubert; et al. (2018). "Aloe Genus Plants: From Farm to Food Applications and Phytopharmacotherapy". International Journal of Molecular Sciences 2018; 19 (9): 2843.

4. Rodd, Tony; Stackhouse, Jennifer, (2008). Royal Botanic Gardens, Kew. "Aloe". World Checklist of Selected Plant Families. . Retrieved 2013-02-25. 1897 5-. Trees: a Visual Guide. Berkeley: University of California Press 2008; p. 131.

5. Gurpınar SS, Devrim B, Eryılmaz M. (2019). "In-vitro antibacterial activity of lactobacilli metabolites loaded hydrogel formulations against pseudomonas aeruginosa". Universal Journal of Pharmaceutical Research 2019; 4(4):1-6.

6. Shargi AH., Aboied M, ME I, Magbool FF. "Improved highperformance liquid chromatography/mass spectroscopy (hplc/ms) method for detection of anthraquinones and antioxidant potential determination in Aloe sinkatana". Universal Journal of Pharmaceutical Research 2020, 5(2):1-6.

7. Mane RS, Vedamurthy AB. "Critical review on Bombax ceiba, Aloe vera and Ximenia americana". Universal Journal of Pharmaceutical Research 2020: 5(2):1-6.

8. Fentaw, Eshetu; Dagne, Kifle; Wondimu, et al. (2020). "Uses and perceived sustainability of Aloe L. (A.sphodelaceae) in the central and northern Highlands of Ethiopia". South African Journal of Botany 2020.

9. Kaokabah N, Al-Qubati A, Al-Naqeb G. (2020). "Anti-obesity effects of Pulicaria jaubertii e. Gamal-eldin in high fat dietinduced rats". Universal Journal of Pharmaceutical Research 2020; 5 (5): 1-6.

10. Al- Hajj MA; Al-Shamahy HA, Alkhatib BY, Moharram BA. (2018). "In vitro anti-leishmanial activity against cutaneous leishmania parasites and preliminary phytochemical analysis of four yemeni medicinal plants". Universal Journal of Pharmaceutical Research 2018; 3(4):1-6.

11. World Health Organization. "Cancer". 12 September 2018. Retrieved 19 December 2018.

12. Jemal A, Bray F, Center MM, Ferlay J, Ward E, Forman D. (2011). "Global cancer statistics" 2011; Ca. 61 (2): 69-90.

13. Al-Maktari LA, Al-Nuzaili M, Al-Shamahy HA, Al-Hadi A, Ishak AA, et al. (2021). Distribution of Hematological Parameters Counts for Children with Leukemia in Children's Cancer Units at Al-Kuwait Hospital, Sana'a City: A CrossSectional Study. Adv Can Res \& Clinical Imag 2021; 3(2).

14. Masdoose SMH, Nasher AT, El-Zine MA, Al-Akwa AAY, AlShamahy HA, Al-labani MA. (2021). Histologic and radiographic study of pathologic change in complete impacted 
third molars dental follicles. Universal Journal of Pharmaceutical Research 2021; 6(1):43-48.

15. El-Zine MAY, Ali MAA, and Al-Shamahy HA. "Prevalence of cns tumors and histological recognition in the operated patients: 10years experience in Yemen". Universal Journal of Pharmaceutical Research 2021; 6(2):1-6.

16. Alhadi1 AM, El-Zine MA, IshaK AA, Al-Shamahy HA. (2021). "Childhood Leukemia in Yemen: The Main Types of Childhood Leukemia, its Signs and Clinical Outcomes". EC Paediatrics 2021; 10(5):1-6.

17. El-Zine MA, Alhadi AM, Ishak AA, Al-Shamahy HA. Prevalence of Different Types of Leukemia and Associated Factors among Children with Leukemia in Children's Cancer Units at Al-Kuwait Hospital, Sana'a City: A Cross- Sectional Study. Glob J of Ped \& Neonatol Car 2021; 3(4):1-6.

18. Cassileth BR, Deng G. "Complementary and alternative therapies for cancer" (PDF). The Oncologist.2004; 9 (1): 80 89.

19. Al-Fatimi M, Friedrich $U$ and Jenett-Siems K. (2005). Cytotoxicity of plants used in traditional medicine in Yemen. Fitoterapia 2005, 76: 355-358.

20. Mothana RA, Al-Musayeib NM, Matheeussen A, Cos P and Maes L (2012). Assessment of the in vitro antiprotozoal and cytotoxic potential of 20 selected medicinal plants from the island of Soqotra. Molecules 2012; 17: 14349-14360.

21. Mothana RA, Lindequist U, Gruenert R and Bednarski PJ. (2009). Studies of the in vitro anticancer, antimicrobial and antioxidant potentials of selected Yemeni medicinal plants from the island of Soqotra. BMC Complement Altern. Med 2009; 9: 7.

22. Awadh Ali NA, Jülich WD, Kusnick C and Lindwquist U. Screening of Yemeni medicinal plants for antibacterial and cytotoxic activities. J. Ethnopharmacol. 2001; 74: 173-179.

23. What Is CAM? Archived 8 December 2005 at the Wayback Machine National Center for Complementary and Alternative Medicine. Retrieved 3 February 2008.

24. Vickers A. (2004). "Alternative cancer cures: "unproven" or "disproven"?". Ca.2004; 54 (2): 110-118.

25. Bazeeb AS (2002). The medicinal plants in Yemen ( $3^{\text {rd }}$ edn. ed). EL-Ershad Press: Sana'a, Yemen.

26. Al-Oqail MM, Farshori NN, Al-Sheddi ES et al. (2013). In vitro cytotoxic activity of seed oil of fenugreek against various cancer cell lines. Asian Pac. J. Cancer Prev.2013; 14: 18291832.

27. Solowey E and Lorberboum-Galski H. (2014). Evaluating medicinal plants for anticancer activity. Sci. World J.2014; 721402: 1-12.

28. Johnson IS, Armstrong JG, Gorman M and Burnett Jr JP. The vinca alkaloids: A new class of oncolytic agents. Cancer Res.1963; 23: 1390-1427.

29. Wall ME, Wani MC, Cook CE, Palmer KH, McPhail AT and Sim GA. Plant antitumor agents. I. The isolation and structure of camptothecin, a novel alkaloidal leukemia and tumor inhibitor from Camptotheca acuminata. J. Amer. Chem. Soc1966; 88: 3888-3890.

30. Wani MC, Taylor HL, Wall ME, Coggon P and McPhail AT. Plant antitumor agents VI. The isolation and structure of taxol, a novel antileukemic and antitumor agent from Taxus brevifolia. J. Amer. Chem.Soc 1971; 93: 2325-2327.

31. Chen TJ, Jeng JY, Lin CW, Wu CY and Chen YC. Quercetin inhibition of ROS-dependent and independent apoptosis in rat glioma C6 cells. Toxicology 2006; 223: 113-126.

32. Moon JY, Mosaddik A, Kim H, Cho M, Choi HK, Kim YS and Cho SK. The chloroform fraction of guava (Psidium cattleianum sabine) leaf extract inhibits human gastric cancer cell proliferation vi induction of apoptosis. Food Chem 2011; 125: 369-375.

33. Saklani A and Kutty SK. Plant-derived compounds in clinical trials. Drug discovery today, 2008; 13: 161-171.

34. Heo BG, Park YJ, Park YS, Bae JH, Cho JY, Park K, Jastrzebski Z and Gorinstein S (2014). Anticancer and antioxidant effects of extracts from different parts of indigo plant. Indus. Crops Prod., 56: 9-16.

35. Elsayed EA, Sharaf-Eldin MA and Wadaan M. In vitro evaluation of cytotoxic activities of essential oil from Moringa oleifera seeds on HeLa, HepG2, MCF-7, CACO-2 and L929 cell lines. Asian Pac. J. Can. Prev 2015; 16: 4671-4675.

36. Abdolmohammadi MH, Fouladdel Sh, Shafiee A, et al. Anticancer effects and cell cycle analysis on human breast cancer T47D cells treated with extracts of Astrodaucus persicus (Boiss.) Drude in comparison to doxorubicin. DARU 2008; 16: 112-118.

37. Fujika T, Furumi K, Fujii H, et al. Antiproliferative constituents from umbelliferae plants. A new furanocoumarin and falcarindiol furanocoumarin ethers from the root of angelica japonica. Chem. Pharm. Bull 1999; 47: 96-100.

38. Kim YJ, Liu RH, Rychlik JL and Russell JB. The enrichment of a ruminal bacterium (Megasphaera elsdenii YJ-4) that produces the trans-10, cis-12 isomer of conjugated linoleic acid. J. Appl. Microbiol 2002; 92:976-982.

39. Kumi-Diaka $\mathbf{J}$ and Butler A. Caspase- 3 protease activation during the process of genistein induced apoptosis in TM4 cells. Biol. Cell, 2000; 92: 115-124.

40. Farshori NN, Al-Sheddi ES, Al-Oqail MM et al. Cytotoxicity Assessments of Portulaca oleraceaand Petroselinum sativum Seed Extracts on Human Hepatocellular Carcinoma Cells (HepG2). Asian Pac. J Can. Prev 2014; 15: 6633-6638.

41. Worthen D, Ghosheh $\mathrm{O}$ and Crooks $\mathrm{P}$. The in vitro anti-tumor activity of some crude and purified components of black seed, Nigella sativa L. Anticancer Res 1998; 18: 1527-1532.

42. Watson RR and Preedy VR (Eds.). Bioactive foods and extracts: Cancer treatment and prevention. CRC Press. 2010. 